\title{
GREEN ENTREPRENEURSHIP: LITERATURE REVIEW AND AGENDA FOR FUTURE RESEARCH
}

\author{
Ik Muo (Ph.D) \\ Olabisi Onabanjo University, Ago-Iwoye, Ogun State, Nigeria. \\ muo.ik@oouagoiwoye.edu.ng, muoigbo@yahoo.com \\ Adebayo Azeez, A. \\ Doctoral Student (Management), Olabisi Onabanjo University, Ago-Iwoye, Nigeria. \\ bayoazeez34@gmail.com \\ ORCID ID: https://orcid.org/0000-0001-6973-8044
}

\begin{abstract}
Advocacy for pro-environmental behaviour in the business arena is on the increase. Yet, many businesses have continued to indulge in "business-as-usual" practices, which are preoccupied with profit maximization objectives at the expense of all other social benefits. Such anti-environment practice has little or no regard for flora and fauna wellbeing. Hence, the main objective of this study is to review, explore and synthesize current views in the field in view of clarifying relevant concepts in green entrepreneurship context. Also, to identify behavioural and performance standards required of green entrepreneurship growth and development. To achieve the study objectives, we adopted integrative review of literature methodology. Concerning the findings, the paper identified new trends in green entrepreneurship and identified the need to clarify some relevant concepts, such as: industry life cycle, entrepreneurship knowledge sharing, institutional framework, entrepreneurship financing, green entrepreneurship decision-making process among others. We also identified the need to properly delineate the process leading to the practice of green entrepreneurship as a departure from the old entrepreneurship philosophy. Therefore, we recommend that further studies should endeavour to focus on identifying the step-by-step processes involved in the green entrepreneurship practice for the possibility of wider accessibility and ease of understanding of prospective green entrepreneurs in the interest of green entrepreneurship growth and development. Finally, we identified the dearth of literature with change management scholars' view and contributions to the emancipation of green entrepreneurship from the cocoon of traditional entrepreneurship management practice hence, we threw it open for future research undertaking.
\end{abstract}

KEYWORDS: Born green firm, green entrepreneurship, green economy, innovation, sustainability.

JEL CLASSIFICATION CODES: L26, M10, O14, O30, Q00.

Received: September $27^{\text {th }}, 2019$

1st Revision: October 17 th, 2019

Accepted: November 27th, 2019

DOI: 10.2478/IJEK-2019-0007

Reference: Muo, I., Azeez, A.. (2019). Green Entrepreneurship: Literature Review and Agenda for Future Research. International Journal of Entrepreneurial Knowledge, 7(2), 17-29. doi:10.12345-0007

\section{INTRODUCTION}

The role of entrepreneurship in the progress of societies has been well recognized (Schumpeter, 1934; Dean \& McMullen, 2007). Paradoxically, the same entrepreneurship has been extensively indicted for negative impacts on the society from its business activities. Such unsustainable business practices have been described by researchers as "business-as-usual model" (Mrkajic, Murtinu \& Scalera, 2019; Demirel, Cher Li, Rentocchini \& Tamvada, 2019). Thus, various institutions such as the United Nations embarked on several educational and enlightenments programmes at different levels calculated to create awareness amongst people on ecological sustainability matters in relation to business management (Pachecho, Dean \& Payne, 2010). These interventions aimed at expanding knowledge 
scope on green entrepreneurial drives include the Stockholm Conference in 1972, Rio De Janeiro Earth Summit 1992, Montreal Convention, Kyoto Protocol and Framework Convention on Climate Change among others. For instance, Farinelli, Bottini, Akkoyunlu and Aerni (2013) emphasize entrepreneurs' ability to migrate from dirty traditional business model in which business organizations are over reliant on the economic profit at the expense of sustainable development which was the main thrust of green entrepreneurship. To this end, the Organisation for Economic Cooperation and Development (2011) advocates for policy mechanisms that would encourage green entrepreneurship in view of reconfiguring the global economic narrative towards environmental friendliness (OCED, 2011). Thus, being conscious of biodiversity among the players in the global economic landscape is sacrosanct. However, in the opinion of O'Neill and Gibbs (2016), old unsustainable business practices have hindered the attainment of global aspiration to achieving low carbon economy hence, aggravating the threatening of the planet (earth)'s integrity. In other words, inability of entrepreneurs to conduct their business within the purview of green entrepreneurship represents failure to recognize opportunities in greening. Therefore, Dean and McMullen (2007) observe that green entrepreneurs are taken advantage of market failure of old business practices by filling these need gaps in the emerging green markets. Furthermore, the need to identify prospects and challenges in the process of going green as entrepreneurs search for opportunities in this regard is equally of important (Esty \& Winston, 2009). Thus, this led to the springing up of business ventures with green outlook. Hence, green ventures lay emphasis on efficiency, innovation, market acceptability, revenue growth, flexibility, effective risk and relationship management and other market benefits (Ambec \& Lanoie 2008; Porter \& Van der Linde 1995).

In addition to the above, due to the negative effects of unsustainable business practices of organizations', which usually manifest in form of environmental pollution, attendants destruction of the natural environment and other valuables, organizations or entrepreneurs should be aware of the consequences of their actions or inactions in this regard. Universally, sustainable development has been recognized as a significant issue that must be carefully considered in any strategic session or discourse, be it business organization, government or society (Kulkarni \& Pammar, 2019). For instance, the World Commission on Environment and Development (Commission, 1987) defines sustainability as the development that meets the needs of the present generation, without compromising ability of the future generations to meet their own needs. In the same vein, Rahman, Nezakati, Ho and Ong (2016) describe sustainable development as a contemporary approach to development that seeks to accomplish the balance between the environment, social and economic goals. Thus, considering the importance of sustainability and many embedded benefits to the betterment of the generality of global citizenry, the growth as well as the development of this important field of study should be the priority for all stakeholders. Since conceptual and theoretical clarity is a precondition for advancement of science vis-à-vis particular field of study, there is a compelling need for clarifications of relevant concepts such as 'born green firms', 'green start-ups', 'eco-oriented start-ups', 'already established firms' to avoid confusion in their usage. However, eco-oriented start-ups' and already established firms' concepts, which means consciously created pro-environmental and later turned environmentally responsible firms, are used interchangeably in this paper. In that, 'already established green firm' represents conventional businesses which later realized the need for greening and adapted accordingly.

Furthermore, Hussain (2018) argues that environmental sustainability is attracting increase attention. Unfortunately, how entrepreneurs got involved in green entrepreneurship in which they are able to contribute immensely to socio-environmental development of a society remained yet unclear. Since both green entrepreneurship firms are known as pro-environmental or environmental friendly or responsible firms, the concern should be to establish or invest in businesses that satisfy specific societal needs without having to undermine entrepreneurs own moral responsibility to preserve nature. For green posterity, entrepreneurs are expected to leverage on the green force of creative destruction, being a formidable platform to build competitive advantage in the contemporary market. However, the researchers believe that very little is known about the characteristics of green entrepreneurship (old or new) with regard to the process involved in penetrating the market and recording innovative performance despite efforts of previous scholars (e.g Criscuolo \& Menon, 2015; Farineli et al., 2013; 
Esty \& Winston, 2009). In addition, very few studies (e.g. Costantini \& Mazzanti, 2012; Sunny \& Shu, 2017; Hörisch, Kollat \& Brieger, 2017) have highlighted unresolved issues in the green entrepreneurship field as well as investigating green entrepreneurship from the perspective of change management despite the fact that the role of change management in any change process is germane. Hence, this paper focuses on the clarification of terms concerning environmental sustainability from the green entrepreneurship viewpoint. More specifically, this study aims at highlight key factors in entrepreneurship sector and set new agenda for future research direction. More so, we observe that change management scholars are yet to show appreciable interest in the field of greening which accounted for paucity of literature with change management perspectives.

\section{LITERATURE REVIEW}

\subsubsection{The Concept of Green Entrepreneurship}

Despite the observed rapid growth in the general field of green study, green entrepreneurship, as a field of study is still at its infancy. For instance, Pachecho et al. (2010) observe that there are some crossroad conceptual issues from the related fields such as Business Economics, Entrepreneurship, Finance, and Accounting, which are yet unresolved. O’Neill and Gibbs (2016) posit that entrepreneurs do experience dilemma in determining what undertakings constitute green entrepreneurship. To alleviate this dilemma, researchers at various occasions tried to define or describe green entrepreneurship for ease of understanding. Green Project (2012) for instance, defines green entrepreneurship as activities that are consciously addressing environmental/social problems/needs through implementation of entrepreneurial ideas amidst high risks and expectation of net positive impact on environment and financial sustainability. The authors go further to describe a green entrepreneur as one who starts and runs an entrepreneurial venture that is designed to be green in process and products. More so, Sunny and Shu (2017) suggest that green entrepreneurship should be defined in terms of adopted technological line of production or firm's activities. Also, Dale (2018) describes green entrepreneurship as a story telling process through which an entrepreneur obtains supports from stakeholders to pursue his/her ambitions. Literature shows that due to the premature stage of green entrepreneurship, scholars have not been able to agree on a universally acceptable definition for it (Demirel et al., 2019). According to the Buck Consultants (2011), 60 percent of businesses today are measuring efficiency through green programmes out of which 78 percent of them achieve power efficiency, two-thirds indicate heating/cooling and paper savings while 60 percent are cutting costs on water consumptions. Hence, in the overall, about 69 percent of the respondents indicated that they are already exploring green in their different endeavours, which represent an increase over the previous year's figures. In support of this, Khan (2015) opines that the only strategic solution to the problem of sustainability is for entrepreneurs to establish their businesses and rely on "go green" for prosperity and long term survival.

Furthermore, the level at which some businesses resort to the use of "green-washing" to lure unsuspected public into their brand through marketing gimmicks further reemphasize the potency of green practice to growing consumers base for certain brands. For instance, researchers (e.g. Darnall \& Edwards, 2006; Zhaojun, Jun, Yali \& Ying 2017) have observed that true green enterprises are bound to enjoy high level of customer loyalty despite the growing interruption of green-washing. Thus, unscrupulous businesses pretending to be green or pro-environmental for undue market advantage can only have their way in the short-run. In other words, businesses firms that have come to the realization of the necessity of greening are now being strategically positioned for sustainable market opportunities compared to those that are pretending to integrate greening into their management processes just when they are not. Although, the challenge being faced by the young green entrepreneurs in this regard cannot be underestimated. These cchallenges, which range from the lack of adequate government supports to the difficulty in assessing funds and markets among others, need to be addressed should green entrepreneurship be widely embraced. However, the resolve to be environmentally oriented and 
compassionate establishments gave green entrepreneurs the resilience to surmount these challenges. Hence this genuineness of purpose ended up given them good reputation of environmental friendly firms with products and services, which customers would gladly patronise. Apparently, it is in our own interest to rally round in support of the new born green firms which stand for sustainability in all ramifications. In other words, it behooves on every stakeholder to see that young green born firms survive to fulfill their purposes.

\subsubsection{The Concept of Creative Green Entrepreneur}

There has been an increasing advocacy for conducive environment for biodiversity, which led to the emergent of green field of study courtesy of creative intelligence. For instance, Demuth (2014) views green creative entrepreneurship as an entrepreneur's ability to obtain stakeholders' approval for his ideas, takes control of the value chains and gets rewarded for his ingenuity to solve environmental problems. The author further argues that entrepreneurs' ability to attract investors for their creative ideas defines the level of success attained through innovative efforts. Meanwhile, Zhaojun et al. (2017) argue that green entrepreneurs' tendency to explore different scenarios due to flexibility and adaptability rooted out of creativity often results in superior solution to business and societal challenges. Similarly, Yousuf, Awang and Iranmaneseh (2017) argue that green entrepreneurs are perceived as disruptive thinkers who are capable of salvaging the sociological landscape from environmental menaces. Thus, entrepreneurs' ability to begin at any level presents them with the advantages of green market opportunities towards sustainability. In addition, Malavisi (2018) posits that green entrepreneurs are those who are involved in modern green business practices through creative and innovative competencies. However, to mitigate global environmental challenges, Dale (2019) argue in favour of green creativities, which he describe from green entrepreneurship perspective as a revolutionary solution to the current social, economic and environmental challenges. Thus, creative entrepreneurship is a coordination of skills and other resources (human and material) towards solving socioeconomic problems through legitimate products/services that bring about financial rewards and sense of fulfilment to the owners.

In view of the above, business environment griped with increased competition, such that customers now have quick access to market information, is leading to products getting obsolete faster. By implication, entrepreneurs are constantly under unnecessary pressure not only to come up with new innovation leading to state-of-the-art products but also, to achieving quick capital turnaround from market acceptability hence, the need to take decisions faster. According to Schumpeter (1934), innovation and entrepreneurship are veritable tools for the development of societies because innovation allows entrepreneurs to take advantage of bigger opportunities for originality which tends to enhance profitability. In other words, through innovative ideas of entrepreneurs, goods and services that are targeted at solving particular needs are developed with attendant socioeconomic benefits capable of improving the society. Thus, economic growth in an environmentally sustainability manner has been recognized as essential condition for human and societal wellbeing (Merkajiw et al., 2019). Although, one may argue that having good life is hinged on many other factors such as peaceful coexistence, having adequate financial resources, having access to balance diet, adequate clothing, good housing, clean water but it is paramount that all these aforementioned factors are subordinate to the environment. Hence, individual and collective economic activities of the society have a direct impact on the environment with some consequences on the planet (earth). For example, Demuth (2014) argues that firms' unsustainable business practices are causing excessive wastes far higher than what can be safely absorbed by the biosphere thereby overburdening the planet's biocapacity. Meanwhile, the problem of climate change does not know geographical boundaries and as such once it strikes, it affects anything within the rage of the nature at a particular point in time. In other words, humanity has transcended its allotted ecological resources as a result of incautious ecological footprints in the course of business activities. Therefore, entrepreneurs' role in proffering enduring solutions to ongoing environmental challenges occasioned by unsustainable business practices cannot be underestimated. Thus, a nation's living standard is proportional to its production capacities in relation to its adopted business models hence, only through the green business model can a nation develop green economy. 


\subsubsection{The Concept of Firm's Life Cycle in Green Entrepreneurship}

Firm's life cycle is the progression of a firm from the time the it was launched in the business world to as long as it can survive within the environment. Thus, so many factors exist in the environment that constitute both opportunities and challenges to the firm during its life cycle. Ability of a firm to decipher those factors and use them to its advantage would define how far it would go in its business endeavour. According to Barbieri, Ghisetti, Gilli, Marin and Nicolli (2016), firm's ability to innovate and commercialise is largely dependent on the stage at the technological and industry lifecycle. In other words, which stage a firm is in its life cycle has an impact on its ability to embrace or adapt technologically. For instance, Malavisi (2018) posits that firm's life cycle and innovative performance underlie its level of success in its chosen sector while, Coad, Segarra and Teruel (2016) indicate that whatever the ability of young new born green firms to penetrate a market and irrespective of innovation or technology adaptability and stage it is on a life cycle scale, it tends to encounter certain difficulties. On the contrary however, Demire et al. (2019) observe that already-established large firms do enjoy economies of scale which, make adoption of certain innovation or technology a bit easy for them to leverage upon in gaining competitive advantage as against the infant firms.

Furthermore, Merkajiw et al. (2019) argue that although innovation process can be executed at different stages of a firm life cycle, new firms tend to incur high costs on research and development (R\&D) as well as training of employees whereas, the old established firms tend to be efficient in this regard due to economies of scale experience and gained reputation. However, literature reveals that green entrepreneurship is preponderance in terms of success compared to traditional firms in the long-run despite the initial challenge in technological life cycle at the point of market entry (Verreynne \& Meyer, 2010; Marin, Marzucchi \& Zoboli, 2015). However, to say that the issue of firm's life cycle is conditioned on the positive outcomes of green entrepreneurship in terms of innovation performance is an understatement because the firm has to fine-tune its existing processes and platform to accommodate new technologies or process. All these would involve consumption of resources which if supported and green entrepreneurship is able to migrate successfully, it would go a long way to safe guard the integrity of our earth planet which had already been over burden by poor environmental management of non-green business firms. For instance, Banerjee and Dutta (2017) argue that sincere integration and implementation does not only send strong signal to others in the business community in terms of getting them aware of need for greening their own business processes too but also leading to the creation of more green products and practices and enhancement of good living for flora and fauna.

\subsubsection{The Concept of Institutional Structure in Green Entrepreneurship}

Institutional structure can be described as a relatively stable pattern of behaviour of a group of people within a particular region or sector. According to Muhammad and Anuge (2016), institutional structure is an important factor in any type of business landscape. Typical example of institutional framework is the oil sector with the related legal frameworks and norms within which the participants are expected to relate. Thus, upon the discovery of oil in many third world countries occasioned by soaring prices in the 70 s accelerated industrialisation occurred, which of course came at the expense of human and natural environment. Against this backdrop, many people acclaimed to be friends of the earth rose against unsustainable business practices by holding various entrepreneurs to account environmentally. Dale (2015) posits that efforts to minimize negative effects of business operations on the environment gave rise to the Stockholm declaration in 1972, Bucharest World Council of Churches conference in 1974, Rio de Janeiro Earth Summit in 1992, among others. During this struggle, the phrase "sustainable development" was coughed out as a slogan used in solidarity for environmental wellness which lately transformed into "green" or "greening" revolution. According to Shapira, Gök, Klochikhin and Sensier (2014), entrepreneurs are the ones behind businesses understanding the benefits of green initiatives and embed environmental objectives into their business aspirations is key for green entrepreneurship development. In the opinion of Darnall and Edwards (2006), green entrepreneurship can exist in two ways namely; 'already established' firms that migrate into greening and new 'born green' firms that 
rooted in the funders' concern for socioenvironmental wellness. In other words, green entrepreneurship could either be accidental or deliberate. Therefore, new born green firms are considered originally eco-oriented that tend to operate in an environmental friendly consistent manners towards the restoration of the lost socio-environmental sanity in our society. While, the already established firms which, suddenly realized the need to become green tend to operate in environmentally inconsistent manners (Pacheco et al., 2010). This obvious difference in green entrepreneurship types might not be far from the issue of sincerity of purpose in the struggle for taking advantage of green consumerism in the market.

Moreover, Meyskens and Carsrud (2013) argue that born green firms' primary focus is on proactive environmental management while, O’Neill and Gibbs (2016) assert that through holistic approach that transcends formal and informal divide is required in consideration of supportive policies and programmes for green entrepreneurship growth and development. Consequently, Dale (2018) observes that new born green firms usually start very small in form of micro, small and medium enterprises (MSMEs) from just spin-offs and then go through rough and tough process before eventually finding their foot through green reputation and market acceptance. Thus, should new born green firms exist side by side with their already-established large counterparts, efforts should be made to cater for the vulnerability of the new born green firms through government's interventions to make green economy dream realisable (World Bank, 2018; Ball \& Kittler, 2017; Suudin \& Brown, 2017). This is because green economy facilitates achievement of economic growth amidst less environmental pollution and natural disasters. For instance, Costantini and Mazzanti (2012) assert that economy is the driving force of production and reproduction of social services in which it translates to growth and development greenly over time. Hence, this should be a major focus for every responsible entrepreneur. Specifically, government as a key institutional actor has an important role to play in making sure that it provides adequate supports for green entrepreneurship on the one hand and create an enabling environment for green economy to thrive in another hand. However, Hörisch et al. (2017) argue that since the need to cater for diverse interests including entrepreneurs' own value reorientation and beliefs are what led to the legitimate passion for new green ventures, which sets out to taking advantage of emerging opportunities in the environment then, certain benefits should be open to the green entrepreneurs for such entrepreneurial undertakings. Not only that, Zhaojoun et al. (2017) indicate that, green economy (eco-concerned capitalisms) promoters naturally find fulfilment in the realization of their own personal dreams despite challenges that might come their way in the process of making green products and services available. this makes them appear energetic and unstoppable. Thus, it is apt to have stringent environmental policies that would set standard of behaviours for the citizenry in order to deter environmental-opportunist entrepreneurs from taking undue advantage of the green market.

\subsubsection{The Concept of Greenwashing in Green Entrepreneurship}

Nature-friendly words such as "eco", "bio", and "organic" sustainability are being used rhetorically by some unscrupulous firms just to deceive unsuspecting consumers to believe that these firms are being conscious of the environment in their business operations (Coad et al., 2016). It has been observed that firms are deliberate in their choice of "greenwashing" habit which literally means to mislead the public through marketing campaigns (Consoli, Marin, Marzucchi \& Vona, 2016; Junior, Galleli, GallardoVàzquez \& Sảnchez-Hernȧndez, 2016). Thus, this widespread usage of deceptive green message for market acceptability indicates that firms are now aware that consumers have sympathy for the natural environment and biodiversity. Although, in the midst of these marketing gimmicks, consumers tend to still identify genuine pro-environmental brand(s) that they prefer to patronize at the end of the day. No wonder Dale (2019), argues that consumers are better informed about the negative impact of entrepreneurial activities on their socio-environmental wellbeing today than ever hence, they have started to consider pro-environmental behaviours of each firm and product before finally actualising their buying decisions. According to Bannamar and Gressel (2015), unless entrepreneurs at all levels agree to be genuinely committed to greening, collective aspiration for just and sane society would continue to remain a surreal. Thus, firms that desired to enjoy customers' loyalty should not only produce and market green products and services but must also be able to convince the customers that 
green is actually their watchword and adhere to green initiative jealously toward achieving environmental sustainability. Although, this cost would be inevitably worthwhile in the long-run when the firm eventually gained green reputation which tends to pay off for any initial cost incurred handsomely. For instance, Tee, Abdulahi, Din, Abdulahi \& Wu (2017) argue that it is economically counterproductive for a firm to interpret being pro-environmental as an unnecessary burden and then go ahead to indulge in greenwashing. The authors argue further that the cost incurred in the process of becoming environmentally responsible can only be higher in the short-run because green reputation would surely bring much higher benefits in the long run.

Furthermore, the act of 'greenwashing' may be regarded as 'economic fraud' because any firm which indulges in it technically would renounce its environmental responsibilities due to the false belief that the cost of being ecofriendly or responsible is unnecessary to bear. O'Neil and Ucbasaran (2016) argue that green reputation represents one of the strong marketing tools of the modern age hence, more products are being packaged in such a way that people would believe they are truly eco-friendly or at least, better than the competitors' own products that are known to be harmful to the environment. Junior et al. (2016) state that although, while some of the supposedly green firms which indulged in greenwashing over-sell their environmental benefits through marketing gimmicks, the genuine proenvironmental brands would eventually be identified and patronized by the public. Hence, the former would eventually lose out of the market upon the availability of the facts behind the figures in the public domain while the eco-oriented business products take over the stage. Taking a cue from this popular saying: "he who kills by the sword shall die by the sword" makes it probable for greenwashers to be haunted by their hypocrite in due course. In any case, greenwashing is unethical marketing practice that will inevitably come back with time to expose whoever found solace in it. More so, the higher the investment in the deceptive green products marketing, the lower the commitment to sustainable environmental practice (Mrkajic et al., 2019; Yousuf et al., 2017). Although, greenwashing may not be completely bad as a practice in some sense because it can help society to become conscious of environmental issues because if firms consistently lay claims (genuinely or not) on sustainability through products/services via marketing communication just to attract consumers, it may lead to gradual shift away from the status-quo (business-as-usual) in business operations (Rahman et al., 2016). Be that as it may, greenwashing remains a deceptive marketing tool and unethical profit-making process in the firms' green marketing efforts.

\subsection{THEORETICAL REVIEW}

\subsubsection{Legitimacy Theory}

Legitimacy theory as an addendum to the real institutional theory proposes that entrepreneurs should have knowledge about their institutions and structures within the remit of their operating environment (Demuth, 2014). These entrepreneurs should be able to identify and understand these institutions and structures before they could gain legitimacy to provide any goods or services for public acceptance. For instance, Hörisch et al. (2017) posit that institutions are deep-seated aspects of the social structures with tendency to define or issue authoritative guidelines, which must be followed by the firms or entrepreneurs. Similarly, Khan (2015) argues that unless there is an equilibrium between the economic growth for wealth accumulation and protection of the environment, no institution can gain legitimacy let alone sustainable development. Legitimacy theory is one of the most recently discovered alternatives within the remit of institutional theory which enjoins entrepreneurs to leverage on the institutions to gain legitimacy needed for survival (Jones \& Gethinger, 2016; Shapira et al., 2014). Thus, legitimacy in this context represents a perception of the nature of the relationship between a firm and other institutions within the purview of its operations vis-à-vis the societal norms and values all of which must remain in tandem with one another. This is so because greening is a sustainability oriented business management approach that has come to right historical wrongs done by the old business management approach to business operations. It is therefore expedient for smart entrepreneurs to start 
embracing greening in their entrepreneurial adventures in the new world of business. In other words, "green" is a new world order that must be supported by all.

\subsubsection{Knowledge Spillover Theory}

Often times, business advantages and opportunities emanate from the internally stored knowledge. According to Audretsch (1995), business knowledge acquired and retained internally over time amounts to available knowledge stockpile, which can also serve as a good basis for knowledge spillover for further entrepreneurship development. In the same vein, Acs, Audretsch, Braunerhjelm and Carlsson (2009) observe that the knowledge spillover theory helps entrepreneurs to take advantage of available opportunities from the recently discovered knowledge through the first stage of innovative ideas generation to the commercialization phase. Thus, knowledge spillover theory of entrepreneurship tends to stimulate new business start-ups in a particular region due to the awareness of initiatives earlier held on eco-oriented start-ups and sectorial-based policies for local communities (Colombelli \& Quatraro, 2017; Barbieri et al., 2016). Thus, regional based knowledge diversity may aid green business start-ups in which complementary technological diversity for green entrepreneurship growth and development are embraced. In other words, regional knowledge stock deposit portends advantage for the green start-ups in different areas of business hence, it is expedient to suggest green firms convergent and focus on knowledge creation, storing and dissemination toward gaining competitive advantage.

\subsubsection{Multiple Stakeholder Perspective}

Despite the long-held belief of the classical economists that stakeholders tend to benefit from firm's economic prosperity in form of wealth (profit) spillover, neglect of the environment by businesses is an injustice to stakeholders. For instance, Muo and Ariyo (2018) argue that classical economists' argument in support of efficacy of 'invisible hand' in regulation of business and human affairs does not always hold true. Considering Muo and Ariyo's argument, one can only remember the rate of environmental degradation with attendant ill-heaths ensuing from unsustainable business practices although, this is no longer sustainable in the contemporary world. For instance, the level of externalities usually borne out from anthropogenic at the expense of the natural environment and biodiversity is enough a reason for green entrepreneurship to be promoted. In addition, Frederik, Layla and Stephen (2017) posit that environmental pollution and greenhouse gas emission (ghg) are adjudged to be responsible for climate change problem with lots of threats to the humanity rooted out of anthropogenic. Similarly, Hassan and Kouhy (2016) argue that businesses affect stakeholders in both positive and negative ways depending on the relationship each stakeholder has with the business. While the authors indicate that the positive sides include the provision of products/services that meet particular societal needs, provision of job opportunities and advancing improvement in peoples' living standard, the negative sides include incessant dominance of spaces, exploitation of workers, and extortion of the public through profiteering, environmental degradation among others. Also, Muhammed (2018) observes that the negative externalities caused by businesses outweigh the positive impacts they had on stakeholders. Therefore, we base our argument against traditional business model in favour of green entrepreneurship on the basis of the existence of multiple stakeholders to the business within the environment. Hence the narrowly defined businesses goals as profit maximization is out of date.

\section{AIM AND METHODOLOGICAL BASES}

The aim of this study is to explore various perspective to green entrepreneurship with a view to simplifying some unresolved key concepts and synthesizing current views in the field. Specifically, we set new agenda for future research trend on the emerging field of green entrepreneurship. However, the methodology adopted to achieve objective of the study was an integrative review of literature. With this, researchers were able to explore historical, contextual, and new trends in green entrepreneurship through systematic search approach to online and hard-copy of relevant publications in the field. 


\section{$4 \quad$ RESULTS}

In the course of the study, we identify the rarity of studies in the field which have been able to articulate step-by-step movement of old established firms into the modern green entrepreneurship domain. Hence, we argue that a lot still need to be done to ensure holistic clarification of key concepts in order to aid development of green entrepreneurship. Also, we observe that concepts such as industry life cycle, entrepreneurship knowledge stock, knowledge spill-over, institutional frameworks, entrepreneurship financing, green entrepreneurship decision-making processes are all open for further clarifications. More so, we identify that the number of old established firms and new born green firms (green entrepreneurship) are on the increase due to the consumers' awareness of the benefit of greening as well reflecting in their buying decisions. Relatedly, we equally observe the challenges facing new born green firms to penetrate the market some of which include old established firms' dominance and lack of adequate policy supports. However, it can be inferred that the chances for green entrepreneurship success due to public yearning for sustainability is higher. Also, we articulate the mode of departure from the old entrepreneurship management philosophy into the newer sustainable oriented green entrepreneurship management model. Last but not the least, we discover that entrepreneurs with business-as-usual model which was narrowly focused on profit maximization are the ones indulged in "greenwashing" knowing that $21^{\text {st }}$ century consumers loyal only to the green businesses and products. In other words, importance of green entrepreneurship in proffering an enduring solution to the global environmental problems cannot be ooverrated.

\section{$5 \quad$ DISCUSSION}

On a global scale, appreciable attention has been shifted to the green business model or processes perhaps for its ability to bring about "sustainability". This development was instigated by the deleterious effect of unsustainable businesses practices of the old business model. Continuous contribution into environmental pollution (air, water and land) endangering humanity and even the planet (earth) integrity compelled the world to form a common front toward proffering sustainable solution to the global environmental crisis. In the process, businesses and even economy are being checkmated through regulations, policies and treaties. Regrettably, it dawned on us that these legal instruments are less effective thereby making little or no impact in abating global environmental crisis. Since, it has been widely acknowledged that most of these environmental problems emanated from business activities, scholars are of the opinion to address it from the root-cause hence, need for business practice reorientations and advocacy for voluntary environmental practices by businesses. However, the principle of green entrepreneurship if carefully harnessed it is capable of helping the world to curtail the propensity of environmental incidences in our society. Thus, green practices entail reduction in the paper and other natural resources, stock consumption and increase electronic storage/filling, car sharing, job sharing, teleconferencing and virtual interviews, recycling, telecommuting, online training, energy efficiency among others. Of course, green entrepreneurship is an emerging field but we found the trace of collaboration among the scholars and practitioners alike in exploring the newness of green entrepreneurship in view of achieving wider understanding and propagation of basic principles, processes, programmes, procedures, and practices in green entrepreneurship management.

Furthermore, in accordance with Khan (2015)'s account where he argues that leadership is one of the critical factors militating against general acceptability of green entrepreneurship, we also point to the fact that processes and workforce needed to be infected with green initiatives. In addition, we observe that institutionalization of training and development suitable for entire workforce from the top managers to the floor supervisors plus holistic integration and involvement of staff in direct communication are part of enablement for green firms. After all, it the green attitude that can instigate green behaviours which in turn reinforce green practice in the firms. For this to happen, green entrepreneurs must learn to incentivize the process such that green contributions are identified and 
rewarded to get a popular buy-in of every member of staff within an establishment. Thus, some of the direct benefits of green entrepreneurships be it in an already well established firm that later joined green train or a new born green firm that is consciously eco oriented, include to minimization of energy cost and other nonrenewable resources costs, enhanced sustainability of the process and gains, free dissemination of green messages among employees, customers, shareholders and other stakeholders to show that the firm actually cares for the natural environment.

More so, it is important to recognize that the benefits of green entrepreneurship spanned beyond the immediate business operational and corporate goals and objectives accomplishment to include other benefits that are not necessarily captured in the organizational goals yet critical for the society at large. These indirect benefits may include treating the effluents from the business operations before it is let out to ensure clean less-diluted air in the environment for citizens to enjoy freshness of breathing at all times. Again, we maintained that another essence of green entrepreneurships is the introduction and implementation of environmentally friendly business initiatives that fostering greater efficiency, low staff turnover, improve employees' engagement and retentions and ultimately gaining of competitiveness. Some of these reasons and benefits of green entrepreneurship we have discussed related to what Banerjee and Dutta (2017) earlier identified when they concluded that treaties, policies and regulations should be made to support green practice in our firms by making it mandatory and reward voluntary green entrepreneurship at the same time in order to eradicate or minimize negative impacts on the society and biodiversity. Unfortunately, as some responsible firms keep finding efficient ways of curbing their environmental footprints, many others who are synonymous with greenwashing remained indifferent even at this critical time the world is bent on preserving the natural environment for better and healthier eco system. However, reorientation of workforce about compelling need to reintegrate environmental success indicators into the existing financial indices towards sustainable development basically requires green policies, procedures and programmes presided over by the strong leadership commitment to achieve sustainability. Thus, the common belief that business that are just implementing green programmes may encounter preliminary challenges is to an extent valid but the likelihood that the efforts would pay off at the end is much higher. Thus, entrepreneurs can either green their existing businesses or simply enter into green entrepreneurship. In any case, the primary concern should be to make our world a conducive and better place for us all to live in hence, need for academic institution to partner with businesses, government and non-governmental institutions in promoting green practice.

The paper concludes that benefits of green entrepreneurship are enormous. Some of these benefits may include efficiency to own firm, creation of community goodwill (the basis for amity relationship with the host communities, employees and other stakeholders), consistent open feedback loop (to receive and disseminate useful information from/to the general public) as some of many opportunities open to organizations with genuine green programs. Furthermore, we note that there are still some unresolved issues in the field of green entrepreneurship. Also, the paper highlighted a need for green entrepreneurship to maintain a cluster-like arrangement and knowledge database for effective dissemination of contemporary green information and clarification of entrepreneurship conceptual definitions. The study equally underscores some knotty issues at the inter-disciplinary crossroads, need for green entrepreneurship policy inclusiveness, reason for and danger in greenwashing. Specifically, the paper provides a new lens at viewing green entrepreneurship in order to understand the role of entrepreneurship as a bridge to building a sustainable green economy in support of Demirel et al. (2019) call in a fascinating study on the behaviour of born green firms and already established firms. More so, the paper identifies the influence of globalization and modernization in business processes vis-à-vis unprecedented pressure being mounted on the business firms to embrace greening in order to realize sustainable development as some of the reasons businesses have to review their operating plans, policies, procedures and programs. 
Yet, we indicate that greening of the business happened at various levels of business operations. Specifically, the paper simplifies the concept of green entrepreneurship, described emergent, growth process and benefits of green entrepreneurship. Also, we elucidate related green entrepreneurship concepts and strategies for nurturing green entrepreneurship as well as differentiated between the new born green firms and old already-established firms. In addition, we conclude that new born green firms stand a chance to benefit more from external green strategies in terms of products/services and customers' accessibility and loyalty compare to their conventional entrepreneurs counterparts. More so, we argue that leveraging on internal green strategies like pro-environmental behaviours of employees and green reputation are formidable assets for competitive advantage. We therefore shed light on the link between green technology and firms. Particularly, the paper identify that very little is known concerning the role of change management in the green entrepreneurship literature. Since greening is a form of innovation that requires behavioural changes and habit modification, it is necessary to understand how these change process unfolds hence, need for change management experts contribution to the field of greening. Therefore, we recommend that future research focus on addressing this research concern. Lastly, we acknowledge the limitations in the study which include inability of the authors to collect and analyse data and test research hypotheses.

\section{REFERENCES}

Acs, Z. J., Audretsch, D. B., Braunerhjelm, P., \& Carlsson, B. (2009). The knowledge spillover theory of entrepreneurship. Journal of Small Business Economics, 32(1), 15-30.

Ball, C. \& Kittler, M. (2017). Removing environmental market failure through support mechanisms: insights from green start-ups in the British, French and German energy sectors. Journal of Small Business Economics, 2(3), 1-22.

Banerjee, S., \& Dutta, A., B. (2017). Green HRM: A brief review. Rainbow Multidisciplinary Pre Reviewed Annual Journal, 3(1), 1-5.

Bannamar, K., \& Gressel, N. (2015). Forget sustainability: Go for green entrepreneurship. Journal of Thinkers Creative Leadership, 1.17. Retrieved on 16/06/2019 via https://www.think.org/insights/go-for-green-entrepreneurship/

Barbieri, N., Ghisetti, C., Gilli, M., Marin, G., \& Nicolli, F. (2016). A survey of the literature on environmental innovation based on main path analysis. Journal of Economic Surveys, 30(3), 596-623.

Buck Consultants (2011). American businesses are measuring the savings from their green workplace practices more than ever. Retrieved on 14/10/2019 via http://news.xerox.com/pr/xerox/photo.aspx?fid=137069.

Coad, A., Segarra, A., \& Teruel, M. (2016). Innovation and firm growth: does firm age play a role? Journal of Research Policy, 45(2), 387-400.

Colombelli, A. \& Quatraro, F. (2017). Green startups and local knowledge spillovers from clean and dirty technologies. Journal of Small Business Economics, 3(5), 1-23.

Consoli, D., Marin, G., Marzucchi, A., \& Vona, F. (2016). Do green jobs differ from non-green jobs in terms of skills and human capital? Journal of Research Policy, 45(5), 1046-1060.

Costantini, V., \& Mazzanti, M. (2012). On the green and innovative side of trade competitiveness? The impact of environmental policies and innovation on EU exports. Journal of Research Policy, 41(1), 132-153.

Criscuolo, C., \& Menon, C. (2015). Environmental policies and risk finance in the green sector: crosscountry evidence. Energy Policy, 83(1), 38 -56.

Dale, G. (2019). Climate, communism and the age of affluence? A Review of Aaron Bastani in Automated Luxury Communism: A Manifesto, 1-6. Retrieved on 13/07/2019 via www.isreview.org/https://theecologist.org/

Dale, G. (2018).The emergence of an ecological Karl Marx: 1818 - 2018. The legacy of the political economist is fiercely contested, 1.7. Retrieved on 13/07/2019 via https://climatecommunismandtheageofaffluencereview.org/ 
Dale, G. (2015). Origin and delusion of green growth. International Socialist Review, 2(97), 1-5. Retrieved on 23/06/2019 via www.isreview.org/https://isreview.org/issue/97/origins-and-delusionsgreen-growth

Darnall, N., \& Edwards, D. (2006). Predicting the cost of environmental management system adoption: the role of capabilities, resources and ownership structure. Strategic Management Journal, 27(4), 301320.

Dean, T. J., \& McMullen, J. S. (2007). Toward a theory of sustainable entrepreneurship: reducing environmental degradation through entrepreneurial action. Journal of Business Venturing, 22(1), 5076.

Demirel, P., Cher Li, Q, Rentocchini, F. \& Tamvada, J., P. (2017). Born to be green: new insights into the economics and management of green entrepreneurship. Journal of Business Economics, 52(1), 759-771.

Demuth, A. (2014). Green Entrepreneurship: A promising path towards a sustainable future in Tunisia and elsewhere. Internationale Zusammenarbeit (GIZ) GmbH, 4-51.

Esty, D. C., \& Winston, A. S. (2009). Green to gold: how smart companies use environmental strategy to innovate, create value, and build competitive advantage. Journal of building and Engineering, 2(5), $1-13$.

Farinelli, F., Bottini, M., Akkoyunlu, S. \& Aerni, P. (2013). Green entrepreneurship: the missing link towards a greener economy. ATDF Journal, 8(3), 42-48.

Ghisetti, C., \& Quatraro, F. (2013). Beyond inducement in climate change: does environmental performance spur environmental technologies? A regional analysis of cross-sectoral differences. Journal of Ecological Economics, 96(1), $99-113$.

Green Project (2012). An attempt to define green entrepreneurship. NCCR Policy Brief, 6(1), 1-3. http://greentproject.eu/wp-content/uploads/2016/01/Definition-green-entrepreneurship.pdf Retrieved 16/6/19.

Hassan, A. \& Kouhy, R. (2016). From environmentalism to corporate environmental accountability in the Nigerian Petroleum Industry: Do green stakeholders matter? International Journal of Energy Sector Management, 9(2): 227-250.

Hörisch, J., Kollat, J., \& Brieger, S. A. (2017). What influences environmental entrepreneurship? A multilevel analysis of the determinants of entrepreneurs' environmental orientation. Small Business Economics, 48(1), 47-69.

Hussain, A. (2018). Green human resource management HRM) practices in organizations: A Comprehensive Literature Surveyed. Journal of Management Research and Analysis, 5(2), 112-117.

Jones, G \& Gettinger, B. (2016). Alternative Paths of Green Entrepreneurship: The Environmental Legacies of the North Face's Doug Tompkins and Patagonia's Yvon Chouinard. Harvard Business School Working Paper, 10(1), 17-34.

Junior, F., H., Galleli, B., Gallardo-Vảzquez, D. \& Sảnchez-Hernȧndez, M., I. (2016). Strategic aspects in sustainability reporting in oil \& gas industry: The comparative case-study of Brazilian Petrobras and Spanish Repsol. Ecological Indicator, 72(1), 203-214.

Khan, M. (2015). Green human resource management - A prerequisite for sustainable environment. Progress in Science and Engineering Research Journal, 18(3), 1-7.

Kulkarni, P., V., \& Pammar, L., S. (2019). A comparative study of rating systems in green building. Journal of Engineering and Technology, 6(4), 1.3.

Malavisi, A. (2018). The Urgency of the Greening of Ethics. Australasian Journal of Logic, 4(3), 593-609.

Meyskens, M., \& Carsrud, A. L. (2013). Nascent green- technology ventures: a study assessing the role of partnership diversity in firm success. Journal of Small Business Economics, 40(3), 739-759.

Mohammed, A. Y. (2018). International Trade and its Impact on CO2 Emission: Empirical Study of Bahrain. International Journal of Academic Research in Business and Social Sciences, 8(2): 318-333.

Mrkajic, B., Murtinu, S. \& Scalera, V. G. (2019). Is green the new gold? Venture capital and green entrepreneurship. Small Business Economics, 52(4), 929-950.

Muhamad, M., \& Anuge, J. (2016). Exploring the challenge for Sustainable Development in the energy sector: Sociomaterial view of two British and Nigerian cases. World Association of Sustainable Development, 2-14. 
Muo, Ik., \& Ariyo, O., O. (2018). Change in macroeconomic policy frameworks in Nigeria lessons from history. Journal of Policy and Development Studies, 11(4), 1-7.

OECD (2011). Measuring Green Entrepreneurship. Entrepreneurship at a Glance, 23-38. Retrieved on 20/06/2019 via: https://doi.org/10.1787/9789264097711-4-en

O’Neil, I., \& Ucbasaran, D. (2016). Balancing Bwhat matters to $\mathrm{me}^{\wedge}$ with what matters to them^: exploring the legitimation process of environmental entrepreneurs. Journal of Business Venturing, 31(2), 133-152.

O’Neill, K., \& Gibbs, D. (2016). Rethinking green entrepreneur- ship - fluid narratives of the green economy. Journal of Environment and Planning, 48(9), 1727-1749.

Pacheco, D. F., Dean, T. J., \& Payne, D. S. (2010). Escaping the green prison: entrepreneurship and the creation of opportunities for sustainable development. Journal of Business Venturing, 25(5), 464480.

Porter, M. E., \& van der Linde, C. (1995). Toward a new conception of the environmentcompetitiveness relationship. Journal of Economic Perspectives, 9(4), 97-118.

Rahman, A., A., Nezakati, H., Ho, J., A. \& Ong S., T. (2016). Integrating operations, human resource, marketing, and accounting and finance perspectives in sustainable supply chain research. Economic Growth, Environmental Protection \& Social Progress, 11-231.

Schumpeter, J. (1934). The theory of economic development. Cambridge, MA: Harvard University Press.

Shapira, P., Gök, A., Klochikhin, E., \& Sensier, M. (2014). Probing green industry enterprises in the UK: a new identification approach. Journal of Technological Forecasting and Social Change, 85, 93 -104.

Suudin, H. \& Brown, D., A. (2017). Greening the black box: Integrating the environment and management control systems. Journal of Accounting, Auditing and Accountability, 30(3). 620-642.

Tamvada, J. P. (2015). The spatial distribution of self-employment in India: evidence from semiparametric geoadditive models. Regional Studies, 49(2), 300-322.

Tee, M., Abdulahi, R., Din, J., Abdulahi, S. \& Wu, L. (2017). Green SD Adoption using knowledge management facilitation - Motivational perspective. Journal of Theoretical and Applied Information Technology, 5(17): 4291-4301.

Yousuf, N., A., Awang, H., \& Iranmaneseh, M. (2017). Determinants and outcome of environmental practices in Malaysian construction projects. Journal of Cleaner Production, 156(17): 345-354.

Zhaojun, Y., Jun, S., Yali, Z \& Ying, W. (2017). Green, Green, It's Green: A Triad Model of Technology, Culture, and Innovation for Corporate Sustainability. Sustainability. 9, 1-23. 